\title{
Topoisomerase II trapping agent teniposide induces apoptosis and G2/M or S phase arrest of oral squamous cell carcinoma Jinzhong $\mathrm{Li}^{1}$, Wantao Chen ${ }^{* 1}$, Ping Zhang ${ }^{1}$ and Ningyi $\mathrm{Li}^{2}$
}

Address: ${ }^{1}$ Ninth People's Hospital, School of Medicine, Shanghai Jiao Tong University, Shanghai Key Laboratory of Stomatology, Shanghai, 200011, P. R. China and 2Affiliated Hospital, School of Medicine, Qingdao University, Qingdao,266021, P.R.China

Email: Jinzhong Li - lijzh78@sohu.com; Wantao Chen* - chenwantao2002@hotmail.com; Ping Zhang - pingzhang73@hotmail.com; Ningyi Li - liny@qdumh.qd.sd.cn

* Corresponding author

Published: 06 July 2006

World Journal of Surgical Oncology 2006, 4:4I doi:10.1 I86/I477-78|9-4-4I

This article is available from: http://www.wjso.com/content/4/I/4 I

(C) $2006 \mathrm{Li}$ et al; licensee BioMed Central Ltd.

This is an Open Access article distributed under the terms of the Creative Commons Attribution License (http://creativecommons.org/licenses/by/2.0), which permits unrestricted use, distribution, and reproduction in any medium, provided the original work is properly cited.
Received: 21 January 2006

Accepted: 06 July 2006

\begin{abstract}
Background: Teniposide (VM-26) has been widely used in the treatment of small cell lung cancer, malignant lymphoma, breast cancer, etc. However, there are few reports on VM-26 against oral cancers. The present study was designed to identify the effect of VM-26 against oral squamous cell carcinoma in vitro, and to provide evidence for the feasibility and effectiveness of VM-26 for application to the patients with oral cancer.
\end{abstract}

Methods: Human tongue squamous cell carcinoma cell line, Tca8II3, was used. Cells were incubated with different concentrations of VM-26 for a variety of time span. Cisplatin (CDDP) was employed as a control reagent. MTT assay was used to assess the inhibitory rate of Tca8II3 growth. Flow cytometer (FCM), transmission electronic microscope (TEM) and fluorescence staining were employed for determining the cell apoptotic rate. Cell cycle distribution of Tca8I I 3 incubated with VM-26 was examined by flow cytometer assay. Statistic software (SAS 6.12, USA) was used for one-way ANOVA.

Results: The IC50 of VM-26 against Tca8II 3 cells was $0.35 \mathrm{mg} / \mathrm{l}$ and that of CDDP was $1.1 \mathrm{mg} / \mathrm{l}$. The morphological changes of Tca8II 3 cells were observed with fluorescence microscope and TEM. Apoptotic morphological feature could be found in the nucleus. Apoptotic rate of Tca8II3 cells incubated with $5.0 \mathrm{mg} / \mathrm{l}$ of VM- 26 for 72 hours was $81.67 \%$ and cells waere arrested at $S$ phase. However, when exposed to $0.15 \mathrm{mg} / \mathrm{l}$ of VM-26 for 72 hours, G2/M phase increased from $12.75 \%$ to $98.71 \%$, while the apoptotic rate was $17.38 \%$, which was lower than that exposed to $5.0 \mathrm{mg} / \mathrm{l}$ of VM-26.

Conclusion: VM-26 could significantly induce apoptosis of oral squamous cell carcinoma and inhibit cell growth. There may be another pathway to induce apoptosis of oral squamous cell carcinoma cells except for G2/M phase arrest.

\section{Background}

The 5-year survival rate was reported to reach $64.7 \%$ for patients with oral carcinomas, while that for patients at advanced stages was between $20.0 \%$ and $40.0 \%$ [1]. As one of three main therapies, chemotherapy may be a potential method to improve the survival rate and quality of life in patients with oral cancer, especially in advanced cancers. Cancers in oral cavity are different with cancers in 
other regions, which means cancers in this region are less chemosensitive, and there is still no special anticancer drug available, which is a hinder for further improvement of chemotherapeutic treatment against oral cancers. Topoisomerase II (Topo II) exists ubiquitously in cells and plays an essential role in DNA replication, transcription, chromosome formation and separation of sister chromatid [2-4]. Because of its essential role in cell growth, cell-cycle, as well as the high expression in proliferating cells, this enzyme is an ideal target for cancer chemotherapeutic drug $[5,6]$. Virtually every form of cancers that can be cured by systemic chemotherapy were always treated with regimens that focus on (or at least contain) drugs targeted to Topo II [7]. Indeed drugs targeted to Topo II are now indispensable components of systemic chemotherapy schedule which could effectively cure several known types of human cancers. Teniposide (4'-demethylepipodophyllotoxin thenylidene-beta-Dglucoside, VM-26) is a podophyllotoxin derivative and was found to be able to stabilize DNA-Topo II complex in DNA replication, thus damage the DNA and induce cellular apoptosis. It has been shown that in the treatment against small cell lung cancer, malignant lymphoma, breast cancer and ovarian cancer, etc through both clinical findings from chemotherapy results and in vitro chemosensitivity test of tumor specimen, anti-tumor effect on VM-26 was stronger than other chemotherapeutic drugs [8-10]. However, there were yet few reports on VM-26 against oral cancers. The purpose of this present study was to explore the apoptosis and concomitant cell cycle progression of Tca8113 cell treated with VM-26, and to provide evidence for the feasibility and effectiveness of VM26 for application to oral cancers clinically.

\section{Methods Cell line}

Tca8113 cell line derived from a patient with tongue squamous cell carcinoma, was used in this study and cultured in RPMI 1640 medium supplemented with $10 \%$ calf serum, 200,000 u/l penicillin and 200,000 u/l streptomycin. Cells were cultured in $25 \mathrm{ml}$ culture flasks with $2 \times$ $10^{5}$ cells $/ \mathrm{ml}$, in humidified atmosphere with $5 \% \mathrm{CO}_{2}$ at $37^{\circ} \mathrm{C}$.

\section{Drugs and reagents}

VM-26 (Bristol-Myers Squibb Co. USA, List: 3075-9), was dissolved in sterile double distilled water to a concentration of $1 \mathrm{~g} / \mathrm{l}$, and stored at $-20^{\circ} \mathrm{C}$. Cisplatin (CDDP, Qilu Co. China, List: 9908012) was dissolved to a final concentration of $0.1 \mathrm{~g} / \mathrm{l} .5 .0 \mathrm{~g} / \mathrm{l}$ MTT [3-(4,5-dimethylthiazol-2yl)-2,5-diphenyl tetrazolium bromide] was purchased from Sigma Chemical-reagent Company. Annexin V-FITC Kit (Becton-Dickinson Co., USA) was used in this experiment.

\section{MTT assay}

Logarithmically growing Tca 8113 cells were trypsinized and made into single cell suspension then plated in 96well culture plate at a concentration of $5 \times 10^{4}$ cells/well, eight columns for VM-26 and seven columns for CDDP in each plate, 3 wells in each column. After 24 hours of incubation, the medium of the 3 wells in each column were replaced with medium containing VM-26 of $0.15 \mathrm{mg} / \mathrm{l}$, $0.5 \mathrm{mg} / \mathrm{l}, 1.5 \mathrm{mg} / \mathrm{l}, 5.0 \mathrm{mg} / \mathrm{l}, 15 \mathrm{mg} / \mathrm{l}$ and $45 \mathrm{mg} / \mathrm{l}$ or CDDP of $0.1 \mathrm{mg} / \mathrm{l}, 0.3 \mathrm{mg} / \mathrm{l}, 1.0 \mathrm{mg} / \mathrm{l}, 3.0 \mathrm{mg} / \mathrm{l}$ and 9.0 $\mathrm{mg} / \mathrm{l}$, respectively. Blank control wells were added medium without drugs. Cells were then cultured for another 24 hours, 48 hours, 72 hours, 96 hours and 120 hours. The supernatants were removed and $20 \mu \mathrm{l}$ MTT solution was added in each well, followed with another 4 hours of culture. The supernatants were discarded carefully and $200 \mu \mathrm{l}$ dimethyl sulphoxide (DMSO, Sigma, USA) was added and shaken vigorously to dissolve the purple precipitation formation. Optical density (OD) of each well was tested using Spectrophotometer (Bio-Tek instruments INC.) with a wavelength of $450 \mathrm{~nm}$. The experiment was repeated in triplicate. The inhibitory rate (IR) of cell growth was calculated with the following formula:

$\mathrm{IR}=\left[\left(1-\mathrm{OD}_{\mathrm{t}}\right) / \mathrm{OD}_{\mathrm{c}}\right] \times 100 \%$

(ODt: OD of cells in treated groups; ODc: OD of cells in control groups).

\section{Cell fluorescence staining}

Cells were incubated with VM-26 of $0.15 \mathrm{mg} / \mathrm{l}, 0.5 \mathrm{mg} / \mathrm{l}$, $1.5 \mathrm{mg} / \mathrm{l}, 5.0 \mathrm{mg} / \mathrm{l}$ and $15 \mathrm{mg} / \mathrm{l}$ for 24 hours, 48 hours, 72 hours, 96 hours and 120 hours, respectively, then washed twice in phosphate buffered saline (PBS) and centrifuged at $1000 \mathrm{rpm}$ for 10 minutes. Cell concentration was adjusted as $1 \times 10^{6}$ cells $/ \mathrm{ml} .10 \mu \mathrm{l}$ of fluorescence dye EB/ $\mathrm{AO}$ was added in $100 \mu \mathrm{l}$ cell suspension, followed with 30 minutes of incubation in dark. Cells were then observed under fluorescence microscope. Nuclei of dead cells were dyed red while nuclei in live cells were dyed green.

\section{Observation of cell ultrastructure using TEM}

Cells were cleansed using dimethylarsinic sodium, and fixed immediately with $2 \%$ glutaraldehyde for $30 \mathrm{~min}$ utes. The cells were then fixed with $1 \%$ osmium tetroxide for 2 hours at $4^{\circ} \mathrm{C}$, dehydrated in ethanol of gradient concentrations, displaced twice using epoxy dimethylmethane, and permeated using 618 embedding solution. Ultrastructure of cell was observed and recorded using TEM Equipment (H-500, Japan).

\section{Cell apoptosis assay}

The cells were incubated with VM-26 of $0.15 \mathrm{mg} / \mathrm{l}, 1.5$ $\mathrm{mg} / \mathrm{l}, 5.0 \mathrm{mg} / \mathrm{l}$ and $15 \mathrm{mg} / \mathrm{l}$ for 12 hours, 24 hours, 36 
hours, 48 hours and 72 hours, respectively. Then the cells and medium supernatant were collected, washed twice with cold PBS, resuspended in $100 \mu \mathrm{l} 1 \times$ binding buffer (contained in Annexin V kit), stained with $5 \mu$ l Annexin VFITC and $5 \mu \mathrm{l} \mathrm{PI}$, and tested using flow cytometer (FACScalibur, Becton-Dickinson Co., USA).

\section{Cell-cycle assay}

Tca8113 cells were treated with VM-26 of $0.15 \mathrm{mg} / \mathrm{l}, 1.5$ $\mathrm{mg} / \mathrm{l}, 5.0 \mathrm{mg} / \mathrm{l}$ and $15 \mathrm{mg} / \mathrm{l}$ for 12 hours, 24 hours, 36 hours, 48 hours and 72 hours, respectively. Then the cells were harvested, fixed in cold $70 \%$ ethanol for 30 minutes, and resuspended in $1 \mathrm{ml}$ PBS. The cell suspensions were treated using $100 \mu \mathrm{l} \mathrm{RNase}$ of $1 \mathrm{~g} / \mathrm{l}$ for $30 \mathrm{~min}$, and stained with $100 \mu \mathrm{l}$ PI of $50 \mathrm{mg} / \mathrm{l}$ in dark for 30 minutes, and then the cells were tested using FCM. The cell cycle distribution was analyzed using ModFit LT 3.0 software.

\section{Statistics}

Data were analyzed with one-way ANOVA using SAS statistical software $(6.12$, TS20).

\section{Results}

Dose-dependent manner of VM-26 and CDDP against Tca8 I I 3 cells

$0.5 \mathrm{mg} / \mathrm{l}$ of VM-26 showed significantly inhibitory effect in a dose-dependent manner. Cells shrank and roundshaped, accompanied with increasingly plasma vacuoles formation. Incubated with $0.5 \mathrm{mg} / \mathrm{l}$ of VM-26 (1/30 of average plasma concentration) for 72 hours, cell growth was inhibited significantly, and $83.58 \%$ Tca 8113 cells were dead. IC50 of VM- 26 was $0.35 \mathrm{mg} / \mathrm{l}$ (figure 1 ). However, $0.3 \mathrm{mg} / \mathrm{l}$ of CDDP (1/10 of average plasma concen-

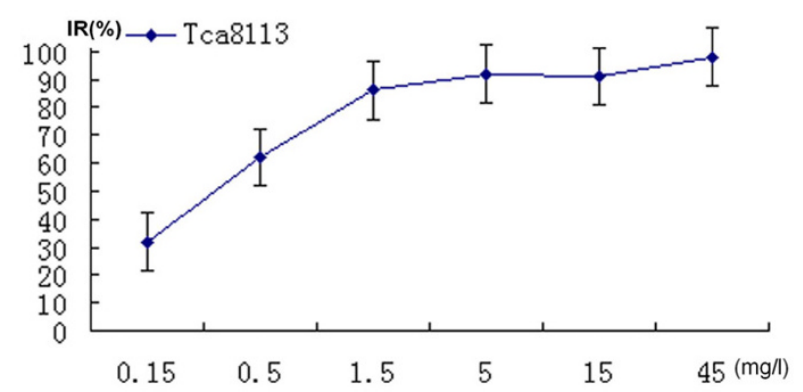

Figure I

VM-26 inhibited the proliferation of Tca8I I 3 cells in a dosedependent way (cells were treated for 72 hours) according to the results of MTT assay. The inhibitory rates reached plateau when the dose of VM-26 increased to $1.5 \mathrm{mg} / \mathrm{l}$. The IC50 of VM-26 was $0.35 \mathrm{mg} / \mathrm{l}$. The figure was the representative of three independent experiments. tration) could not inhibit cell growth significantly. The IC50 of CDDP was $1.1 \mathrm{mg} / \mathrm{l}$ (figure 2).

\section{Time-dependent manner of VM-26 and CDDP against Tca8 I I 3 cells}

Both VM-26 and CDDP showed growth inhibitory potency to Tca8113 cells in a time-dependent manner. VM- 26 of $5.0 \mathrm{mg} / \mathrm{l}$ significantly inhibited the proliferation of Tca8113 cells. The inhibitory rate was $40.65 \%$ at 24 hours. As time went on, the inhibitory rate reached $80.9 \%$ at 72 hours and $92.1 \%$ at 96 hours. VM-26 had a stronger inhibitory potency than CDDP at the similar level of plasma concentration at any time span (figure 3 ).

\section{Apoptosis assay of Tca8I I 3 cells}

Fluorescence staining intuitively showed the inhibitory effect of VM-26. The nuclei of control Tca8113 cells stained with $\mathrm{EB} / \mathrm{AO}$ dye were green (figure $4 \mathrm{~A}$ ). Treated with VM-26 of $0.5 \mathrm{mg} / \mathrm{l}$ for 24 hours, some nuclei became red and some dyed into yellow. With the concentration of VM-26 increasing or time lapsing, more cells became red, which confirmed the time-dependent and dose-dependent manner of VM-26 against Tca8113 cells. Figure 4B show the dead cells after incubation with $5.0 \mathrm{mg} / \mathrm{l}$ of VM26 for 72 hours.

The ultrastructure changes during cell death were observed compared with the feature of blank control cells (figure 4C) using TEM. The cells treated with VM-26 showed typical apoptotic phenomenon. The nucleus became smaller, karyoplasm was concentrated and karyotheca was crimpled, chromosome condensed into a semilunar shape clinging to the karyotheca and the cellular membrane (figure 4D). The results indicated that Tca8113 cells were killed by VM-26 through apoptotic induction.

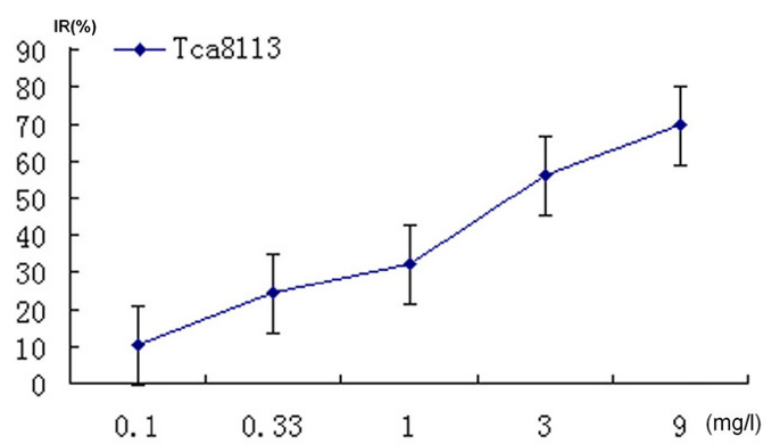

Figure 2

CDDP inhibited the proliferation of Tca8 I I 3 cells dosedependently (cells were treated for 72 hours) according to the results of MTT assay. The IC50 of CDDP was $1.1 \mathrm{mg} / \mathrm{l}$. The figure was the representative of three independent experiments. 


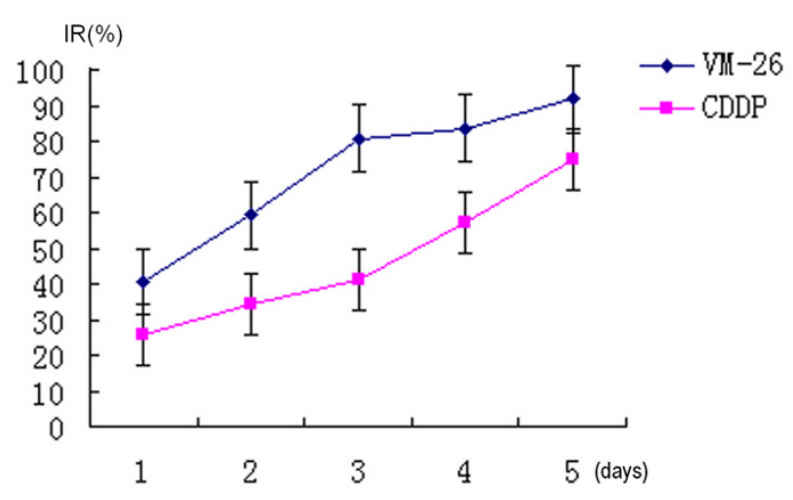

\section{Figure 3}

$5.0 \mathrm{mg} / \mathrm{l}$ of VM-26 and $1.0 \mathrm{mg} / \mathrm{l}$ of CDDP inhibited the proliferation of Tca8I I 3 cells time-dependently according to the results of MTT assay. VM-26 played potent inhibiting effect on the proliferation of Tca8 I 3 cells compared with CDDP with the parallel plasma concentrations. The figure was the representative of three independent experiments.
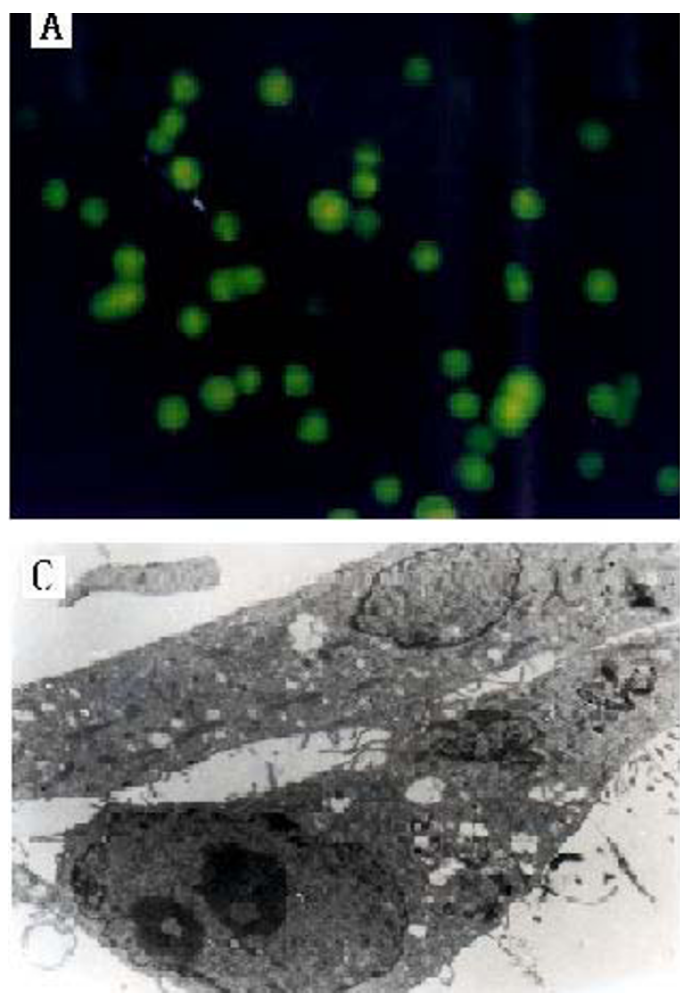

Most Tca8113 cells were killed through apoptosis in a dose-dependent manner, which increased significantly with the increase of VM-26 concentration. Compared the 4 concentrations, $5.0 \mathrm{mg} / \mathrm{l}$ of VM- 26 or $15 \mathrm{mg} / \mathrm{l}$ seemed to induce similar apoptosis in Tca8113 cells, which indicated that $5.0 \mathrm{mg} / \mathrm{l}$ of VM-26 was effective in inducing apoptosis (figure 5). Cells exposed to $0.15 \mathrm{mg} / \mathrm{l}$ of VM-26 seemed to just begin apoptosis at 36 hours, which approximate to population doubling time of Tca8113 cells (38.8 hours). However, cells treated with $5.0 \mathrm{mg} / \mathrm{l}$ of VM-26 began apoptosis at 24 hours and only $3.57 \%$ was viable after 72 hours (figure 6).

\section{Cell-cycle distribution}

Tca8113 cells exposed to VM-26 showed cell cycle arrest in a time-dependent manner. $98.71 \%$ of cells were arrested at G2/M phases after treated with $0.15 \mathrm{mg} / \mathrm{l}$ of VM-26 for 72 hours, (figure 7). Apoptosis of cells seemed to be induced through the G2/M phase arrest. While Tca 8113 cells treated with $5.0 \mathrm{mg} / \mathrm{l}$ of VM-26 cell cycle was arrested mainly in $S$ phase, and higher apoptotic rate occurred in this group (shown in figure 6 and figure 8).
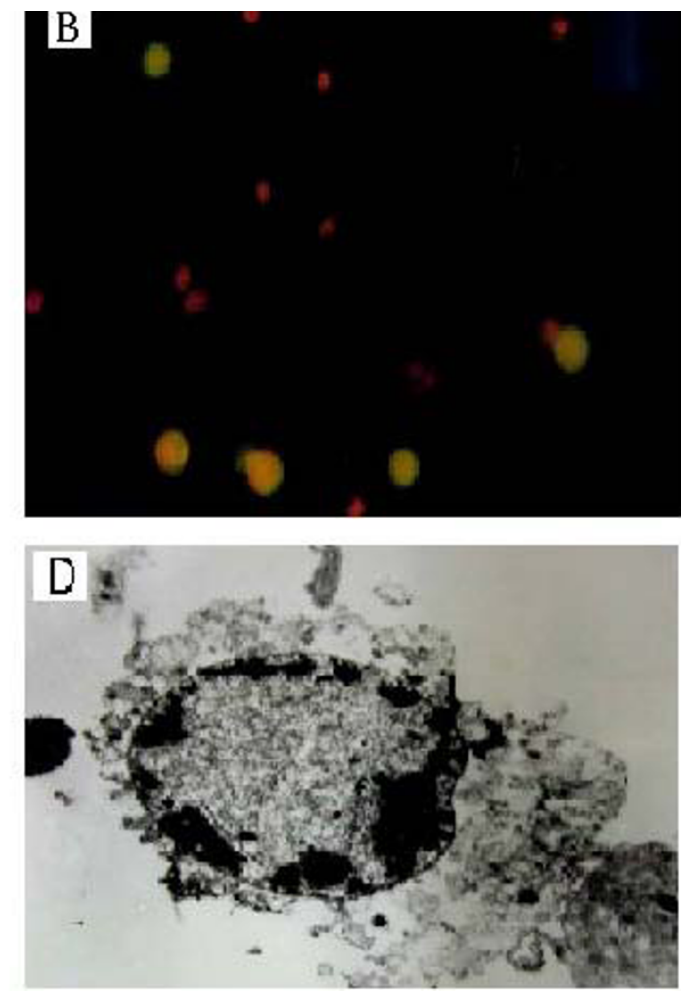

\section{Figure 4}

The morphological changes of Tca8I I 3 cells treated with VM-26. Figure A showed the blank control cells were dyed green using $\mathrm{EB} / \mathrm{AO}$ stained, figure $B$ showed the cells exposed to $5.0 \mathrm{mg} / \mathrm{l}$ of $\mathrm{VM}-26$ for 72 hours were dyed red. Figure $C$ showed the feature of blank control cells, figure D showed the apoptotic phenomenon of Tca8I I 3 cells exposed to $5.0 \mathrm{mg} / \mathrm{l}$ of VM-26 for 48 hours, chromosome condensed into a semilunar shape and clung to the karyotheca (TEM $\times 4000)$. 


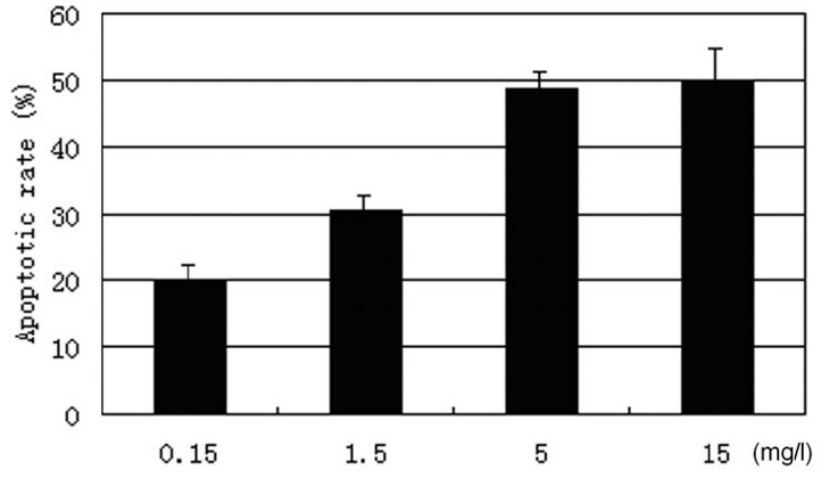

Figure 5

The apoptosis of Tca8I I 3 cells were induced by VM-26 in a dose-dependent manner (for 48 hours) according to the results of Annexin-V/PI assay. $5.0 \mathrm{mg} / \mathrm{l}$ of VM-26 induced similar apoptotic rate as $15 \mathrm{mg} / \mathrm{l}$ of VM-26 did. The results were expressed as mean \pm SD of three independent experiments.

Cell cycle of Tca 8113 cells exposed to $0.15 \mathrm{mg} / \mathrm{l}$ of VM-26 was arrested at G2/M phase, while in another group (containing $5.0 \mathrm{mg} / \mathrm{l}$ of VM-26) cells were arrested at S phase (figure 8).

\section{Discussion}

Topo II has two isomers, TopoII $\alpha$ and Topo II $\beta$. Topo II $\alpha$ is cell-cycle regulated and is abundant in proliferating cells while Topo II $\beta$ predominates in quiescent cells [11]. High expression of Topo II $\alpha$ in tumor tissue is a common phenomenon, and Topo II $\alpha$ is gradually regarded as a sign to judge the extent of tumor cell proliferating [12-14]. Topo II poisons can be classified as DNA-intercalating

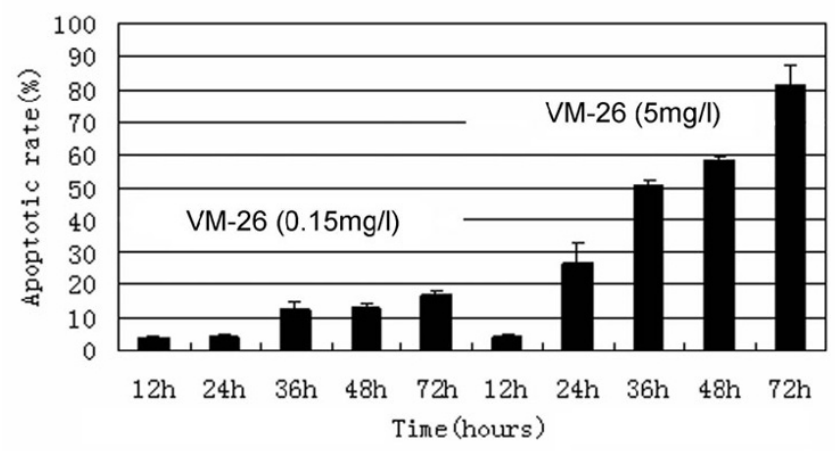

Figure 6

The apoptosis of Tca8I I 3 cells were induced by VM-26 in a time-dependent manner according to the results of Annexin$\mathrm{V} / \mathrm{PI}$ assay. $5.0 \mathrm{mg} / \mathrm{l}$ of VM-26 demonstrated more apoptosisinducing effect on Tca8II 3 cells than $0.15 \mathrm{mg} / \mathrm{l} \mathrm{did}$. The results were expressed as mean \pm SD of three independent experiments.

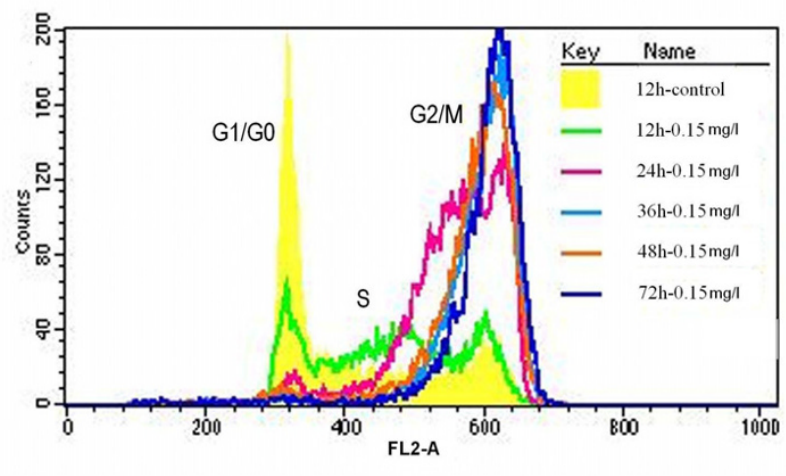

Figure 7

Overlay of cell cycle distributions of Tca8 I I 3 cells exposed to $0.15 \mathrm{mg} / \mathrm{l}$ of VM-26 for a variety of time span. The cells were harvested and analyzed with propidium iodide staining to assess for cell cycle distribution by FACS analysis. The line in yellow, green, red, light blue, brown and blue indicate the cell cycle distributions of control cells, and of cells treated with teniposide for 12 hours, 24 hours, 36 hours, 48 hours and 72 hours, respectively. The cell cycle of Tca8I I 3 cells were obviously arrested at $\mathrm{G} 2 / \mathrm{M}$ phase as time lapsed. The results were expressed as mean \pm SD of three independent experiments.

drug and DNA-nonintercalating drug. The former can damage DNA through inserting the plane portion of its molecular structure, such as the ring of purine or pyrimidine, into the double strands of DNA where Topo II bind-

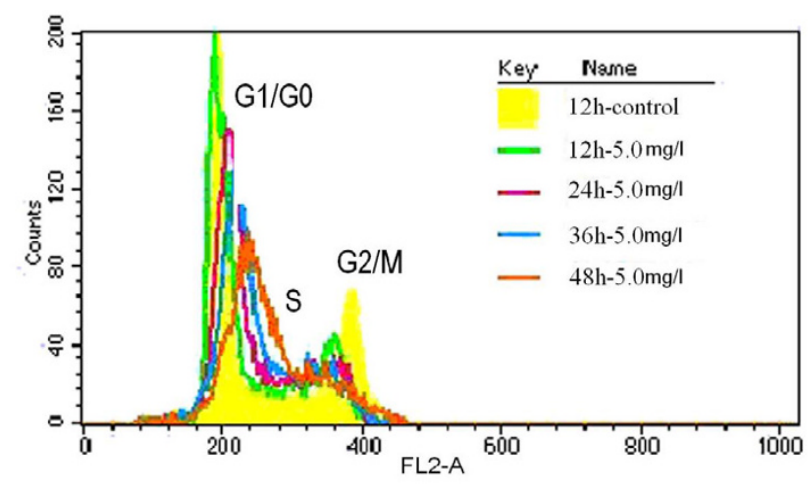

Figure 8

The cells were harvested and analyzed with propidium iodide staining to assess cell cycle distribution by FACS analysis and the results were expressed as mean \pm SD of three independent experiments. Overlay of cell cycle distributions of Tca8I I 3 cells exposed to $5.0 \mathrm{mg} / \mathrm{l}$ of VM-26. The line in yellow, green, red, light blue and brown indicated the cell cycle distributions of control cells, and of cells treated with VM-26 for 12 hours, 24 hours, 36 hours and 48 hours, respectively. The cell cycle of Tca8I I 3 cells were obviously arrested at S phase as time lapsed. 
ing to interfere the enzyme religation of the nicks of the broken DNA double strands, which lead cell to death eventually. However, the mechanism of non-intercalating drug killing tumor cells is still unclear. VM-26 is a kind of non-intercalating TopoII poison. Generally speaking, drug that can inhibit Topo II $\alpha$ is also capable of inhibiting Topo II $\beta$. However, most drugs, especially non-intercalating drugs, are more effective on Topo II $\alpha$ while intercalating drugs are more effective on Topo II $\beta$ [15]. Chen et al [16] applied 8 drugs (CDDP, 5-Fu, PYM, Taxol, VM-26, EADM, VDS and MTX), to test the chemosensitivity of 140 oral cancer specimens before chemotherapy, finding the average inhibitory rate of VM-26 against tumor cells reached $63.76 \%$ while the inhibitory rates of other 7 drugs were less than $30.0 \%$. These oral squamous cell carcinoma specimens seemed not sensitive to E-ADM which is an intercalating Topo II poison.

CDDP was used as a positive control drug because it was in wide clinical use and regarded as a standard chemotherapeutic drug. We chose experimental concentration of these two drugs according to their average plasma concentration because it determined their clinical effects. Both the MTT and the FCM assay indicated that, at $5.0 \mathrm{mg} / \mathrm{l}$ concentration, the potency of VM-26 inhibiting Topo II and inducing apoptosis reached plateau. In any case, 5.0 $\mathrm{mg} / \mathrm{l}$ (1/3 average plasma concentration [17]) VM-26 could induce approximate maximum inhibitory effect on Tca8113 cells in vitro. We found that $5.0 \mathrm{mg} / \mathrm{l}$ of VM-26 could inhibit oral cancer cells significantly after 72 hours incubation; the inhibitory rate reached $92.1 \%$ at 120 hours, which was much higher than those of CDDP at the $1 / 3$ average plasma concentration. VM-26 inhibits the growth of tumor cell in an obvious dose-dependent and time-dependent manner.

The typical apoptotic phenomenon was found in Tca8113 cells treated with VM-26 by TEM, and also, apoptosis were induced by VM-26 both dose-dependently and timedependently. There are many pathways for cells apoptosis, including PKA/camp pathway, T cell receptor pathway, dead receptor pathway and Fas/TNFR1 associated pathway. Mo et al [4] found that the ability of these DNA Topo II inhibitors including VM-26 activating FasL promoter and inducing FasL expression, was correlated with their ability to cause DNA damage. When these permanent DNA breaks were present in sufficient numbers, they initiated a series of apoptosis events that ultimately culminated in cell death [7].

G2 phase arrest was a common phenomenon found in mammalian cells when they were treated with most DNAdamaging reagents [18]. Such G2 arrest has been proposed to be due to induction of G2 checkpoint machinery that allows damaged DNA to be repaired before cells move to the next cell cycle stage $[19,20]$. Chen et al [21] reported that cells treated with VM-26 of higher dosage stopped the cell cycle in S phase, but they found the cells at last be arrested in the G2/M phase if the time of incubation with drug was prolonged and assumed such $\mathrm{S}$ phase inhibition should be a kind of $S$ phase retardation other than arrest. The present study showed only VM-26 of 0.15 $\mathrm{mg} / \mathrm{l}$ could significantly arrest cells in G2/M phase, while VM-26 of $1.5 \mathrm{mg} / \mathrm{l}, 5.0 \mathrm{mg} / \mathrm{l}$ and $15 \mathrm{mg} / \mathrm{l}$ tended to stop cell progression in S phase, and initiated significant apoptosis concomitantly. Thus, this kind of apoptosis was not triggered by G2 checkpoint machinery. This study found apoptosis of cells incubated with VM-26 of $5.0 \mathrm{mg} / \mathrm{l}$ was much more than that of cells with VM-26 of $0.15 \mathrm{mg} / \mathrm{l}$, that is, much more cells died in the $S$ phase than cells did in G2/M phase. So, apoptosis of Tca8113 cells incubated with VM-26 might not be induced by G2/M phase arrest, apoptosis could be induced before cells reached G2 checkpoint. Cells do not always get into G2/M phase when treated with VM-26. There may be another pathway to induce apoptosis of oral carcinoma cells except traditional G2/M phase arrest.

\section{Conclusion}

The present study showed that Tca8113 cells were sensitive to VM-26 and provided evidences for applying VM-26 in oral cancer chemotherapy. The results also showed that low dose and high dose of VM-26 worked in different way and there existed other ways except for G2/M phase arrest.

\section{Competing interests}

The author(s) declare that they have no competing interests.

\section{Authors' contributions}

JL carried out cell culture, cell apoptosis assay, cell cycle assay, performed statistical analysis and drafted the manuscript. WC conceived of the study, carried out MTT assay, cell fluorescence staining and TEM observation, and drafted the manuscript.. PZ helped to draft the manuscript. NL participated in its design and coordination. All authors read and approved the final manuscript.

\section{Acknowledgements}

This work was supported by Key Project of National Natural Science Foundation of China (Grant No. 30330580) and by National Natural Science Foundation of China (Grant No. 301710I4, 30300388). And Supported by Science and Technology Committee of Shanghai Municipality (Grant Number: 014319359,034107002) and by Shanghai Municipal Education Commission(Y0203).

\section{References}

I. Qiu WL: Progress and achievements in diagnosis, treatment and research of oral tumors: 10-year review. Chinese Arch Otolaryngol Head Neck Surg 1996, 3:57-61.

2. Morse-Gaudio M, Risley MS: Topoisomerase II expression and VM-26 induction of DNA breaks during spermatogenesis in Xenopus Laevis. J Cell Sci 1994, 107:2887-2898. 
3. Andreassen PR, Lacroix FB, Margolis RL: Chromosomes with two intact axial cores are induced by G2 checkpoint override: evidence that DNA decatenation is not required to template the chromosome structure. I Cell Biol 1997, 136:29-43.

4. Mo YY, Beck WT: DNA damage signals induction of Fas ligand in tumor cells. Mol Pharmacol 1999, 55:216-222.

5. Heck MM, Earnshaw WC: Topoisomerase II, a specific marker for cell proliferation. J Cell Biol 1986, 103:2569-258I.

6. Liu LF: DNA topoisomerase poisons as antitumor drugs. Annu Rev Biochem 1989, 58:35I-375.

7. Bruden DA, Osheroff $\mathrm{N}$ : Mechanism of action of eukaryotic topoisomerase II and drugs targeted to the enzyme. Biochim Biophys Acta 1998, 1400:139-154.

8. Bepler G, O'Briant $\mathrm{K}$ : In vitro chemosensitivity testing of human non-small cell lung cancer cell lines. Anticancer Res 1998, I8(5A):318I-3185.

9. Van der Gaast A, Splinter TA: Teniposide (VM-26) in ovarian cancer: a review. Semin Oncol 1992, 19(2 Suppl 6):95-97.

10. Nielsen D, Boas J, Engelholm SA, Hansen OP, Dombernowsky P: VM26 in advanced breast cancer. A phase II trial in patients with no prior chemotherapy. Ann Oncol 1992, 3:377-378.

II. Woessner RD, Mattern MR, Mirabelli CK, Johnson RK, Drake FH: Proliferation dependent and cell cycle-dependent differences in expression of the 170-kilodalton and 180 -kilodalton forms of topoisomerase-II in NIH 3T3 cells. Cell Growth Differ |99|, 2:209-2|4.

12. Nakopoulou L, Lazaris AC, Kavantzas N, Alexandrou P, Athanassiadou P, Keramopoulos A, Davaris P: DNA topoisomerase II-alpha immunoreactivity as a marker of tumor aggressiveness in invasive breast cancer. Pathobiology 2000, 68(3): $137-143$.

13. Willman JH, Holden JA: Immunohist Chemical staining for DNA topoisomerase II-alpha in benign, premalignant, and malignant lesions of the prostate. Prostate 2000, 42:280-286.

14. Stathopoulos GP, Kapranos N, Manolopoulos L, Papadimitriou C, Adamopoulos G: Topoisomerase II alpha expression in squamous cell carcinomas of the head and neck. Anticancer Res 2000, 20:177-182.

15. Sabourin M, Osheroff N: Sensitivity of human type II topoisomerases to DNA damage: stimulation of enzyme-mediated DNA cleavage by a basic, oxidized and alkylated lesions. Nucleic Acids Res 2000, 28: 1947- 1954.

16. Chen W, Zhou X, Xu Q, Guo W, Lin L: Chemosensitivity testing of oral cancer with biopsy specimens. Zhonghua Kou Qiang $Y$ Xue Za Zhi 2002, 37:404-407.

17. Fountzilas G, Lim LO, Yunis AA: The inhibitory effects of teniposide and homoharringtonine on the growth of pancreatic carcinoma cells in vitro. Anticancer Res 1988, 8:343-346.

18. Rao PN: The molecular basis of drug-induced G2 arrest inmammalian cells. Mol Cell Biochem 1980, 29:47-57.

19. Hartwell LH, Weinert TA: Checkpoints: controls that ensure the order of cell cycle events. Science 1989, 246:629-634.

20. Murray WA: Creative blocks: cell-cycle checkpoints and feedback controls. Nature 1992, 359:599-604.

21. Chen M, Beck WT: Differences in inhibition of chromosome separation and G2 arrest by DNA topoisomerase II inhibitors Merbarone and VM-26. Cancer Res 1995, 55:1509-15I6.
Publish with Bio Med Central and every scientist can read your work free of charge

"BioMed Central will be the most significant development for disseminating the results of biomedical research in our lifetime. "

Sir Paul Nurse, Cancer Research UK

Your research papers will be:

- available free of charge to the entire biomedical community

- peer reviewed and published immediately upon acceptance

- cited in PubMed and archived on PubMed Central

- yours - you keep the copyright
BioMedcentral 